\title{
PHOSPHORUS FRACTIONS IN SANDY SOILS OF VINEYARDS IN SOUTHERN BRAZIL ${ }^{(1)}$
}

\author{
Djalma Eugênio Schmitt ${ }^{(2)}$, Jucinei José Comin ${ }^{(3)}$, Luciano Colpo Gatiboni ${ }^{(4)}$, Tales \\ Tiecher $^{(5)}$, Felipe Lorensini ${ }^{(5)}$, George Wellington Bastos de Melo ${ }^{(6)}$, Eduardo Girotto ${ }^{(7)}$, \\ Renato Guardini $^{(8)}$, Janaína Heinzen ${ }^{(9)}$ \& Gustavo Brunetto ${ }^{(10)}$
}

\begin{abstract}
SUMMARY
Phosphorus (P) applications to vineyards can cause $P$ accumulation in the soil and maximize pollution risks. This study was carried out to quantify the accumulation of $P$ fractions in sandy soils of vineyards in southern Brazil. Soil samples (layers 0-5, 6-10 and 11-20 cm) were collected from a native grassland area and two vineyards, after 14 years (vineyard 1) and 30 years (vineyard 2) of cultivation, in Santana do Livramento, southern Brazil, and subjected to chemical fractionation of $P$. Phosphorus application, especially to the 30 -year-old vineyard 2 , increased the inorganic $P$ content down to a depth of $20 \mathrm{~cm}$, mainly in the labile fractions extracted by anion-exchange resin and $\mathrm{NaHCO}_{3}$, in the moderately labile fraction extracted by 0.1 and $0.5 \mathrm{~mol} \mathrm{~L}^{-1} \mathrm{NaOH}$, and in the non-labile fraction extracted by $1 \mathrm{~mol} \mathrm{~L}^{-1} \mathrm{HCl}$, indicating the possibility of water eutrophication. Phosphorus application and grapevine cultivation time increased the $P$ content
\end{abstract}

(1) Part of the first author's Master's thesis. Received for publication on June $1^{\text {st }}, 2012$ and approved on February 26, 2013.

(2) Agronomist, MSc in Agricultural Ecosystems Graduation Program (PGA), Doctoral Student in Soil Science, University of Santa Catarina State - UDESC. CAPES fellowship. Av. Luis de Camões, 2090. CEP 88520-000 Lages (SC), Brazil. E-mail: djalma.schmitt@yahoo.com.br

(3) Agronomist, PhD, Associated Professor, Rural Engineer Department (ENR) and PGA at Federal University of Santa Catarina (UFSC). Campus Universitário Reitor João David Ferreira Lima Trindade. Bairro Itacorubi. CEP 88040-900 Florianópolis (SC). E-mail: jcomin@cca.ufsc.br

(4) Agronomist, PhD in Agronomy, Associated Professor, UDESC. Grant in productive supported by CNPq. E-mail: gatiboni@cav.udesc.br

(5) Agronomist, MSc in Soil Sciences, Doctoral Student in Soil Science at Federal University of Santa Maria (UFSM). UFSM. Caixa Postal 221. CEP 97105-900 Santa Maria (RS). CAPES fellowship. E-mail: tales.t@hotmail.com; felipe.lorensini@hotmail.com

${ }^{(6)}$ Agronomist, Researcher Embrapa Uva e Vinho. Rua Livramento, 515. Caixa Postal 130. CEP 95700-000 Bento Gonçalves (RS). E-mail: george@cnpuv.embrapa.br

(7) Agronomist, Doctor in Soil Science, Instituto Federal de Educação, Ciência e Tecnologia do Rio Grande do Sul, Campus Ibirubá. Rua Erly de Almeida Lima, 600, apto 201. CEP 97105-120 Santa Maria (RS). E-mail: girottosolos@gmail.com

(8) Agronomist, MSc in Agricultural Ecosystems Graduation Program (PGA). Energia, Transporte e Saneamento S/C LTDA. Rua Felipe Schmidt, 348/349. Centro. CEP 88010-000 Florianópolis (SC). E-mail: renatoguardini@yahoo.com.br

(9) Agronomy student at UFSC. Undergraduate fellowship. E-mail: heinzen6@gmail.com

${ }^{(10)}$ Agronomist, PhD in Soil Science, Adjunct Professor at Soil Science Department UFSM. Grant in productive supported by CNPq. Email: brunetto.gustavo@gmail.com 


\begin{abstract}
in the organic fraction extracted by $\mathrm{NaHCO}_{3}$ from the 0-5 cm layer, and especially in the moderately labile fraction extracted by $0.1 \mathrm{~mol} \mathrm{~L}^{-1} \mathrm{NaOH}$, down to a depth of $20 \mathrm{~cm}$.
\end{abstract}

Index terms: phosphate fertilization, eutrophication, vineyards.

\author{
RESUMO: FRAÇÕES DE FÓSFORO EM SOLOS ARENOSOS CULTIVADOS \\ COM VIDEIRA NA REGIẼO SUL DO BRASIL
}

\begin{abstract}
As aplicações de fósforo $(P)$ em vinhedos podem causar o acúmulo desse nutriente no solo e maximizar seu potencial poluente. Este trabalho objetivou quantificar as frações de acumulação de Pem solos arenosos cultivados com videiras na região Sul do Brasil. Para isso, amostras de solo foram coletadas nas camadas de 0-5, 6-10 e 11-20 cm em uma área de campo nativo e em dois vinhedos: um com 14 anos de cultivo (vinhedo 1) e outro com 30 anos (vinhedo 2), localizados no município de Santana do Livramento, Rio Grande do Sul (RS), Brasil. As amostras foram secas, moídas e submetidas ao fracionamento químico de P. Os resultados evidenciaram que os teores de P inorgânico aumentaram até $20 \mathrm{~cm}$ de profundidade, principalmente no vinhedo 2 , em especial nas frações lábeis extraídas por resina de troca aniônica e por $\mathrm{NaHCO}_{3}$, na fração moderadamente lábil, extraída por $\mathrm{NaOH}$ 0,1 e 0,5 mol L-1, e na fração não lábil, extraída por $\mathrm{HCl} 1 \mathrm{~mol} \mathrm{~L} \mathrm{~L}^{-1}$, representando potencial de eutroficação das águas. As aplicações de fertilizantes fosfatados na adubação de correção e de manutenção nos vinhedos com maior tempo de cultivo aumentaram os teores de P na fração orgânica extraída por $\mathrm{NaHCO}_{3}$ na camada de 0-5 cm, e na fração moderadamente lábil extraída por $\mathrm{NaOH}$ $0,1 \mathrm{~mol} \mathrm{~L}^{-1}$, até $20 \mathrm{~cm}$ de profundidade.
\end{abstract}

Termos para indexação: adubação fosfatada, eutrofização, vinhedos.

\section{INTRODUCTION}

In the preparation of grapevine planting, the subtropical soils in Brazil are subjected to liming and pre-planting fertilization with phosphate and potassium. After planting the vineyard and diagnosing fertilizer requirements based on soil analysis and expected grape yield (CQFS-RS/SC, 2004), N, P and K were applied to the soil surface, representing the maintenance fertilization. However, nutrient amounts, including $\mathrm{P}$, are not always defined based on technical criteria and, therefore, accumulation of excess $\mathrm{P}$ and fraction modifications must be expected.

Studies on $P$ accumulation and soil fractions have been conducted based on the chemical fractionation technique (Hedley et al., 1982). This technique uses chemical extractors that remove inorganic and organic $\mathrm{P}$ in a sequential procedure, from the most available to the most stable fractions. Anion-exchange resin extracts inorganic $\mathrm{P}$ from labile fractions and $0.5 \mathrm{~mol}$ $\mathrm{L}^{-1} \mathrm{NaHCO}_{3}$ extracts inorganic and organic $\mathrm{P}$ from labile fractions. These two labile fractions may contribute to the nutrient supply of plants and can be transferred by the percolation solution because they are easily desorbed (Gatiboni et al., 2007, 2008). The $\mathrm{P}$ extracted by 0.1 and $0.5 \mathrm{~mol} \mathrm{~L}^{-1} \mathrm{NaOH}$ represents inorganic $\mathrm{P}$ linked to oxides and silicate clays with intermediate binding energy and the organic $\mathrm{P}$ of moderately labile fractions (Cross \& Schlessinger, 1995; Gatiboni et al., 2007). The $\mathrm{HCl}$ extracts inorganic $\mathrm{P}$ contained in the calcium phosphates and strongly adsorbed phosphates. Lastly, soil digestion with $\mathrm{H}_{2} \mathrm{SO}_{4}+\mathrm{H}_{2} \mathrm{O}_{2}+\mathrm{MgCl}_{2}$ extracts the residual inorganic + organic $\mathrm{P}$ of the soil, called recalcitrant $\mathrm{P}$, which may contribute to plant nutrition in extremely P-poor soils (Gatiboni et al., 2007; Santos et al., 2008).

In soils growing annual crops under long-term, successive phosphate applications, organic and inorganic $\mathrm{P}$ fractions are accumulated in the soil at different degrees of binding energy, although the accumulation of the inorganic fractions is generally most pronounced (Negassa et al., 2009; Linquist et al., 2011; Tokura et al., 2011). Few studies on P accumulation in vineyard soils after long-term nutrient application have been published in the international literature and none in Brazil. This study was carried to quantify the accumulated $P$ fractions in sandy soils of vineyards after long-term $\mathrm{P}$ applications in southern Brazil.

\section{MATERIAL AND METHODS}

\section{Site description and treatments}

The study was carried out in the Soil, Water and Plant Tissue Laboratory of the Department of Agricultural Engineering of the Universidade Federal de Santa Catarina (UFSC), (Federal University of 
Santa Catarina) in Florianopolis (SC), Brazil, using soil samples from native grassland and those derived from commercial vineyards located in the municipality of Santana do Livramento in the Campanha Gaúcha region of the Rio Grande do Sul State, Brazil. One of the predominant soils in the region, mostly under native pasture or grapevine, is sandy Typic Hapludalf soil (Soil Survey Staff, 1999), with a sandy surface texture, granite substrate and predominance of 1:1 type clay. The climate is humid subtropical (Cfa), with a mean annual temperature of $18.2{ }^{\circ} \mathrm{C}$ and mean annual rainfall of $1,400 \mathrm{~mm}$.

In December 2010, an area of native grassland with no previous cultivation and $\mathrm{P}$ applications was selected, which was used as reference area and two vineyards of different ages and, consequently, with different sequences of fertilization with $\mathrm{P}$ sources. In vineyard 1 (latitude $30^{\circ} 46^{\prime} 50^{\prime \prime} \mathrm{S}$ and longitude $55^{\circ} 23^{\prime} 22^{\prime \prime} \mathrm{W}$ ), the Tannat cultivar was grafted onto a SO4 rootstock, planted in 1996, at a density of 2,525 plants per hectare $(1.2 \times 3.3 \mathrm{~m})$, in the cordon training system, on an area of approximately 6 ha. In vineyard 2 (latitude $30^{\circ} 47^{\prime} 12^{\prime \prime} \mathrm{S}$ and longitude $55^{\circ} 22^{\prime} 25^{\prime \prime} \mathrm{W}$ ), the Tannat cultivar was grafted onto a $\mathrm{SO} 4$ rootstock, planted in 1980 at a density of 1,429 plants per hectare $(2.2 \times 3.5 \mathrm{~m})$ in the cordon training system, on an area of about 5 ha. In both vineyards, before planting the vines, limestone was applied on the soil surface, followed by incorporation to raise the water $\mathrm{pH}$ to 6.0. In pre-planting fertilization of vineyard 1 and, respectively, $40 \mathrm{~kg}$ and $145 \mathrm{~kg} \mathrm{P}_{2} \mathrm{O}_{5}$ ha $^{-1}$ was applied to the soil surface, with subsequent incorporation. In both vineyards maintenance fertilization was initiated when grape harvesting began in the third year after planting (CQFSRS/SC, 2004), with annual applications of around $50 \mathrm{~kg} \mathrm{P}_{2} \mathrm{O}_{5}$ ha $^{-1}$ year-1 to the soil surface without incorporation. The $\mathrm{P}$ source used throughout the years was generally triple superphosphate. Throughout the years, herbicides were periodically applied to the grapevine rows for weed control, whereas between the rows, spontaneous vegetation was maintained, consisting of Lolium perenne, Paspalum notatum and Trifolium repens. Periodically, this vegetation was mowed and left on the soil surface.

\section{Soil collection and analysis of soil properties and $P$ chemical fractionation}

In January 2011, 14 years after the establishment of vineyard 1 and 30 years after the establishment of vineyard 2 , six randomly located trenches $(0.3 \times 0.5 \mathrm{x}$ $0.5 \mathrm{~m}$ ) were opened in each vineyard, in the plant rows and in the native grassland area adjacent to the vineyards. Soil samples were then collected in the 0-5, 6-10 and 11-20 cm layers and stored. Afterwards, the soil was oven-dried at $\pm 45^{\circ} \mathrm{C}$. The samples were then ground, passed through a sieve ( $2 \mathrm{~mm}$ mesh) and divideid into three portions. The first soil portion was subjected to analysis of the soil particle size distribution by the pipette method (Embrapa, 1997).
In addition, the water $\mathrm{pH}(1: 1)$, and the content of exchangeable aluminum $\left(\mathrm{Al}^{3+}\right)$, calcium $\left(\mathrm{Ca}^{2+}\right)$ and magnesium $\left(\mathrm{Mg}^{2+}\right)$ (extractor $\left.\mathrm{KCl} 1.0 \mathrm{~mol} \mathrm{~L}^{-1}\right)$, and exchangeable K (extractor Mehlich-1) (Tedesco et al., 1995) were determined (Table 1). Total organic carbon was determined following the method proposed by Embrapa (1997). The contents of Fe extracted by sodium dithionite-citrate-bicarbonate (Mehra \& Jackson, 1960) and by ammonium oxalate (Tedesco et al., 1995) were also determined. Cation exchange capacity at $\mathrm{pH} 7.0\left(\mathrm{CEC}_{\mathrm{pH} .0}\right)$ and effective cation exchange capacity $\left(\mathrm{CEC}_{\text {effective }}\right)$, the base saturation of $\mathrm{CEC}_{\mathrm{pH} 7.0}$ and the saturation of $\mathrm{CEC}_{\text {effective }}$ by aluminum were calculated by the equations established by CQFSRS/SC (2004).

The second soil sample portion was subjected to $P$ chemical fractionation, according to the method of Hedley et al. (1982), with modifications proposed by Condron \& Goh (1989), briefly outlined as follows: 1) $0.5 \mathrm{~g}$ soil samples were subjected to sequential extraction with anion-exchange resin; 2) inorganic and organic $\mathrm{P}$ were extracted by $0.5 \mathrm{~mol} \mathrm{~L}^{-1} \mathrm{NaHCO}_{3} ; 3$ ) organic and inorganic $\mathrm{P}$ were extracted by $0.1 \mathrm{~mol} \mathrm{~L}^{-1}$ $\mathrm{NaOH}$; 4) inorganic $\mathrm{P}$ was extracted by $1 \mathrm{~mol} \mathrm{~L}^{-1} \mathrm{HCL}$ and inorganic and organic $P$ was extracted by $0.5 \mathrm{~mol}$ $\left.\mathrm{L}^{-1} \mathrm{NaOH} ; 5\right)$ after the extractions, the remaining soil was dried in a greenhouse at $50^{\circ} \mathrm{C}$ and subjected to digestion with $\mathrm{H}_{2} \mathrm{SO}_{4}+\mathrm{H}_{2} \mathrm{O}_{2}+\mathrm{MgCl}_{2}$ (residual $\mathrm{P}$ ), as described by Gatiboni et al. (2008). Inorganic P of the alkaline extracts of $\mathrm{NaHCO}_{3}$ and $\mathrm{NaOH}$ was determined by the method proposed by Dick \& Tabatabai (1977). In these alkaline extracts, total $P$ was determined by digestion with ammonium persulfate + sulfuric acid in an autoclave. Organic $P$ was computed as the difference between total $P$ and inorganic $\mathrm{P}$. Acid extract $\mathrm{P}$ was determined according to Murphy \& Riley (1962). Phosphorus fractions of the Hedley fractionation were grouped into geochemical P and biological P (Cross \& Schlesinger, 1995). Geochemical $P$ was calculated as the sum of the inorganic fractions plus the residual $\mathrm{P}$ (anionexchange resin $+0.5 \mathrm{~mol} \mathrm{~L}^{-1} \mathrm{NaHCO}_{3}+0.1 \mathrm{~mol} \mathrm{~L}^{-1}$ $\mathrm{NaOH}+0.5 \mathrm{~mol} \mathrm{~L}^{-1} \mathrm{NaOH}+1 \mathrm{~mol} \mathrm{~L}^{-1} \mathrm{HCL}+$ residual $\mathrm{P}$ ), and the biological $\mathrm{P}$ by the sum of the organic fractions $\left(0.5 \mathrm{~mol} \mathrm{~L}^{-1} \mathrm{NaHCO}_{3}+0.1 \mathrm{~mol} \mathrm{~L}^{-1} \mathrm{NaOH}+\right.$ $\left.0.5 \mathrm{~mol} \mathrm{~L}^{-1} \mathrm{NaOH}\right)$.

\section{Statistical analysis}

The results of $\mathrm{P}$ content in different layers of the same native grassland or vineyard soils and the same layer of different native grassland or vineyard soils were subjected to analysis of variance (SAS, 2003). Phosphorus contents were used as dependent and soil depth and site as independent variables. The results of all analyses were tested for significance by the $\mathrm{F}$ test at $\leq 0.05$ probability. Multiple comparisons for $P$ contents, where the result of analysis of variance was statistically significant, were carried out using Tukey's HSD (Tukey's Honestly Significant Difference) test (0.05). 
Table 1. Physical and chemical properties of a sandy Typic Hapludalf soil at a grassland site near vineyard 1 (age 14 years) and vineyard 2 (age 30 years), in three soil layers

\begin{tabular}{|c|c|c|c|c|c|c|c|c|c|}
\hline \multirow{2}{*}{ Soil characteristic } & \multicolumn{3}{|c|}{ Grassland site } & \multicolumn{3}{|c|}{ Vineyard 1} & \multicolumn{3}{|c|}{ Vineyard 2} \\
\hline & $0-5 \mathrm{~cm}$ & $6-10 \mathrm{~cm}$ & $11-20 \mathrm{~cm}$ & $0-5 \mathrm{~cm}$ & $6-10 \mathrm{~cm}$ & $11-20 \mathrm{~cm}$ & $0-5 \mathrm{~cm}$ & $6-10 \mathrm{~cm}$ & $11-20 \mathrm{~cm}$ \\
\hline & & & & & $\mathrm{cm}$ & & & & \\
\hline Clay $^{(1)}\left(\mathrm{g} \mathrm{kg}^{-1}\right)$ & 36.0 & 135.0 & 81.0 & 132.0 & 112.0 & 119.0 & 47.0 & 72.0 & 100.0 \\
\hline $\operatorname{Sand}^{(1)}\left(\mathrm{g} \mathrm{kg}^{-1}\right)$ & 825.0 & 826.0 & 804.0 & 764.0 & 764.0 & 735.0 & 793.0 & 799.0 & 786.0 \\
\hline $\operatorname{Silt}^{(1)}\left(\mathrm{g} \mathrm{kg}^{-1}\right)$ & 139.0 & 39.0 & 116.0 & 104.0 & 124.0 & 146.0 & 160.0 & 130.0 & 114.0 \\
\hline $\operatorname{TOC}^{(2)}\left(\mathrm{g} \mathrm{kg}^{-1}\right)$ & 7.0 & 5.0 & 2.0 & 9.0 & 4.0 & 4.0 & 8.0 & 4.0 & 4.0 \\
\hline $\mathrm{pH}\left(\mathrm{H}_{2} \mathrm{O}\right)^{(2)}$ & 4.0 & 4.0 & 4.2 & 5.9 & 5.3 & 5.3 & 6.0 & 5.8 & 5.7 \\
\hline $\mathrm{K}^{+(3)}\left(\mathrm{mg} \mathrm{kg}^{-1}\right)$ & 27.0 & 27.0 & 22.0 & 90.3 & 52.6 & 34.9 & 60.0 & 43.3 & 36.2 \\
\hline $\mathrm{Ca}^{2+(4)}\left(\mathrm{cmol}_{\mathrm{c}} \mathrm{kg}^{-1}\right)$ & 1.3 & 0.6 & 0.4 & 1.8 & 1.1 & 0.8 & 2.3 & 1.3 & 1.0 \\
\hline $\mathrm{Mg}^{2+(4)}\left(\mathrm{cmol}_{\mathrm{c}} \mathrm{kg}^{-1}\right)$ & 0.7 & 0.4 & 0.3 & 0.7 & 0.5 & 0.4 & 0.8 & 0.5 & 0.5 \\
\hline $\mathrm{Al}^{3+(4)}\left(\mathrm{cmol}_{\mathrm{c}} \mathrm{kg}^{-1}\right)$ & 0.2 & 0.4 & 0.4 & 0.0 & 0.1 & 0.2 & 0.0 & 0.0 & 0.0 \\
\hline $\mathrm{H}+\mathrm{Al}\left(\mathrm{cmol}_{\mathrm{c}} \mathrm{kg}^{-1}\right)^{(5)}$ & 2.3 & 2.1 & 2.0 & 3.0 & 2.9 & 3.3 & 2.1 & 2.5 & 2.3 \\
\hline $\mathrm{CEC}_{\mathrm{pH} 7.0}\left(\mathrm{cmol}_{\mathrm{c}} \mathrm{kg}^{-1}\right)^{(6)}$ & 4.4 & 3.2 & 2.8 & 5.7 & 4.6 & 4.6 & 5.4 & 4.4 & 3.9 \\
\hline $\mathrm{CEC}_{\text {effective }}\left(\mathrm{cmol}_{\mathrm{c}} \mathrm{kg}^{-1}\right)^{(7)}$ & 2.3 & 1.5 & 1.2 & 2.7 & 2.2 & 2.0 & 3.3 & 1.9 & 1.6 \\
\hline $\mathrm{Fe}_{\mathrm{d}}\left(\mathrm{g} \mathrm{kg}^{-1}\right)$ & 4.6 & 4.9 & 5.4 & 10.8 & 10.7 & 10.4 & 5.1 & 4.6 & 5.1 \\
\hline $\mathrm{Fe}_{\mathrm{ox}}\left(\mathrm{g} \mathrm{kg}^{-1}\right)$ & 0.4 & 0.5 & 0.6 & 1.5 & 1.4 & 1.2 & 0.6 & 0.5 & 0.6 \\
\hline
\end{tabular}

(1) Pipette method (Embrapa, 1997); (2) TOC: total organic carbon (Tedesco et al., 1995); ${ }^{(3)}$ Extracted by Mehlich-1 (Tedesco et al., 1995); ${ }^{(4)}$ Extracted by KCl 1 mol L-1 (Tedesco et al., 1995); ${ }^{(5)} \mathrm{H}+\mathrm{Al}=\mathrm{e}^{10.665-1.1483 * \mathrm{pH} \mathrm{SMP}} / 10 ;{ }^{(6)} \mathrm{CEC}_{\mathrm{pH}} 7.0=\mathrm{H}+\mathrm{Al}^{-1}\left(\mathrm{Ca}^{+2}+\mathrm{Mg}^{+2}+\mathrm{K}^{+}\right)$; (7) $\mathrm{CEC}_{\text {effective }}=\mathrm{Ca}^{+2}+\mathrm{Mg}^{+2}+\mathrm{K}^{+}+\mathrm{Na}^{+}+\mathrm{Al}^{3+} ;{ }^{(8)} \mathrm{Fe}_{\mathrm{d}}$ : Fe extracted by dithionite-citrate-bicarbonate; ${ }^{(9)} \mathrm{Fe}_{\mathrm{ox}}: \mathrm{Fe}$ extracted by oxalate.

\section{RESULTS AND DISCUSSION}

\section{Soil properties}

The soils of the uncultivated and unfertilized native grassland area, of the 14-year old vineyard 1 , fertilized with $40 \mathrm{~kg} \mathrm{P}_{2} \mathrm{O}_{5}$ ha $^{-1}$ before planting and with $50 \mathrm{~kg}$ $\mathrm{P}_{2} \mathrm{O}_{5}$ ha $^{-1}$ year -1 throughout grape production, and of the 30 -year old vineyard 2 , fertilized with $145 \mathrm{~kg} \mathrm{P}_{2} \mathrm{O}_{5}$ $\mathrm{ha}^{-1}$ before planting and $50 \mathrm{~kg} \mathrm{P}_{2} \mathrm{O}_{5}$ ha $^{-1}$ year-1 as maintenance fertilization, all have a sandy texture with inherently low $\mathrm{P}$ retention capacity (Table 1).

The total organic carbon contents in the soils of native grassland and vineyards 1 and 2 were highest in the surface layer $(0-5 \mathrm{~cm})$, decreasing along the profile, but the values were relatively low in all layers. This is because soils with a sandy texture, such as the sandy Typic Hapludalf of this study, have low contents of clay and Fe oxides (Table 1), reducing the protection of organic matter and increasing the decomposition process.

The water $\mathrm{pH}$ values in all layers of native grassland soil were lower than 4.5 , but between 5.3 and 6.0 in both vineyards (Table 1). The contents of exchangeable $\mathrm{Ca}^{2+}$ and $\mathrm{Mg}^{2+}$ in all layers tended to be higher in the vineyard than the grassland soils. Higher $\mathrm{pH}$ values in water and higher exchangeable $\mathrm{Ca}^{2+}$ and $\mathrm{Mg}^{2+}$ in the vineyard soils can be attributed to liming of the soil surface prior to grapevine planting, with subsequent incorporation. The Fe content extracted by dithionite-citrate-bicarbonate and ammonium oxalate tended to be higher in all soil layers of vineyard 1 than vineyard 2 and native grassland.

\section{Phosphorus fractions}

In the soil from native grassland and the two vineyards, the highest $\mathrm{P}$ contents in the anionexchange resin fraction were found in the surface soil layer $(0-5 \mathrm{~cm})$ (Table 2), decreasing with depth. However, in the 6-10 and 11-20 cm layers of vineyard 2 , the $\mathrm{P}$ content extracted by anion-exchange resin was higher than in vineyard 1 , and higher in all three layers than in native grassland soil. In the vineyard soils, in the second $\mathrm{P}$ fraction of Hedley's procedure $\left(\mathrm{NaHCO}_{3} 0.5 \mathrm{~mol} \mathrm{~L}^{-1}\right)$, considered as labile, the highest $\mathrm{P}$ content was found in the $0-5 \mathrm{~cm}$ layer of the vineyard soils, while $P$ contents were equal in all layers of the soil under native grassland. However, the $\mathrm{P}$ content extracted by $\mathrm{NaHCO}_{3} 0.5 \mathrm{~mol} \mathrm{~L}^{-1}$ from all layers was higher in vineyard 2 than in native grassland and vineyard 1 soil, with the exception of the $6-10 \mathrm{~cm}$ layer, where the contents of both vineyard soils were equivalent.

The higher $\mathrm{P}$ contents extracted by anion-exchange resin and by $0.5 \mathrm{~mol} \mathrm{~L}^{-1} \mathrm{NaHCO}_{3}$ in the soil layers of vineyard 2 , especially in relation to vineyard 1 , can be attributed to the longer period of phosphate fertilizations. This reinforces the idea that the quantities of phosphate fertilizers applied before planting and as maintenance fertilization exceeded the plant demand and therefore part of this $\mathrm{P}$ can be carried off in a solution flowing on the soil surface 
Table 2. Resin inorganic $\mathrm{P}, \mathrm{NaHCO}_{3}$ inorganic $\mathrm{P}$ and $\mathrm{NaHCO}_{3}$ organic $\mathrm{P}$ fractions in a sandy Typic Hapludalf soil at a grassland site, vineyard 1 (age 14 years) and vineyard 2 (age 30 years), in three layers

\begin{tabular}{|c|c|c|c|c|c|}
\hline$P$ fraction & Soil layer & Grassland site & Vineyard 1 & Vineyard 2 & $\mathbf{C V}$ \\
\hline \multirow{5}{*}{ Resin inorganic $\mathrm{P}$} & $\mathrm{cm}$ & 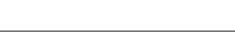 & mg kg-1 & & $\%$ \\
\hline & $0-5$ & $7.7 \mathrm{aB}$ & $22.1 \mathrm{aA}$ & $23.2 \mathrm{aA}$ & 2.37 \\
\hline & $6-10$ & $3.6 \mathrm{bB}$ & $16.2 \mathrm{bA}$ & $17.3 \mathrm{bA}$ & 3.09 \\
\hline & $11-20$ & $2.3 \mathrm{cC}$ & $5.4 \mathrm{cB}$ & $13.2 \mathrm{cA}$ & 2.32 \\
\hline & $\mathrm{CV}(\%)$ & 4.33 & 2.54 & 1.52 & \\
\hline \multirow{3}{*}{$\mathrm{NaHCO}_{3}$ inorganic $\mathrm{P}$} & $0-5$ & $3.1 \mathrm{aC}$ & $18.2 \mathrm{aB}$ & $21.7 \mathrm{aA}$ & 2.69 \\
\hline & $6-10$ & $2.7 \mathrm{aB}$ & $14.0 \mathrm{bA}$ & $15.0 \mathrm{bA}$ & 8.74 \\
\hline & $11-20$ & $2.3 \mathrm{aC}$ & $9.1 \mathrm{cB}$ & $13.5 \mathrm{bA}$ & 14.27 \\
\hline \multirow{5}{*}{$\mathrm{NaHCO}_{3}$ organic $\mathrm{P}$} & $\mathrm{CV}(\%)$ & 26.50 & 9.39 & 5.02 & \\
\hline & $0-5$ & $1.7 \mathrm{bB}$ & $9.6 \mathrm{aA}$ & $8.7 \mathrm{aA}$ & 14.69 \\
\hline & $6-10$ & $2.4 \mathrm{bB}$ & $8.6 \mathrm{aA}$ & $5.0 \mathrm{bAB}$ & 24.95 \\
\hline & $11-20$ & $5.2 \mathrm{aA}$ & $2.1 \mathrm{bB}$ & $5.4 \mathrm{bA}$ & 8.42 \\
\hline & $\mathrm{CV}(\%)$ & 19.04 & 22.72 & 13.97 & \\
\hline
\end{tabular}

(1) Mean values followed by the same letter in the column and by the same capital letter in the row, comparing soil layers, are not significantly different (Tukey test, $\mathrm{p}<0.05$ ).

and by percolation, because of the sandy texture and low Fe oxide content of the vineyard soils (Table 1 ). Moreover, the total $\mathrm{P}$ content in grapevine leaves over the years was generally interpreted as normal $(0.12-$ $0.40 \%$ ) (data not shown) (CQFSRS/SC, 2004) and P application was therefore not recommended; nevertheless, over the years the vineyards received $50 \mathrm{~kg} \mathrm{P}_{2} \mathrm{O}_{5}$ ha $^{-1}$ year $^{-1}$.

It should be noted that the $\mathrm{P}$ amount detected by anion-exchange resin and $0.5 \mathrm{~mol} \mathrm{~L}^{-1} \mathrm{NaHCO}_{3}$, especially in the 6-10 and $11-20 \mathrm{~cm}$ layers of vineyard 2 , after 30 years of phosphate fertilization, were not much higher than in vineyard 1 , subjected to phosphate fertilization for 14 years. This can probably be attributed to $\mathrm{P}$ transformation into more stable forms, not accessed by these extractors, as well as by $\mathrm{P}$ migration to deeper soil layers, especially because the soils have a sandy texture and low Fe oxide content (Table 1). It is also worth mentioning that the results of soil $\mathrm{P}$ extracted by anion-exchange resin and by 0.5 mol L-1 $\mathrm{NaHCO}_{3}$ are similar to results published in other studies (Herlihy \& McGrath, 2007; Boschetti et al., 2009; Tokura et al., 2011) which also used P chemical fractionation and reported that the contents of these two fractions increase with the dose of soluble phosphate fertilizers applied over time. It should also be mentioned that the $\mathrm{P}$ contents extracted by anionexchange resin in the $0-5 \mathrm{~cm}$ layer of both vineyards were considered high (> $\left.20 \mathrm{mg} \mathrm{kg}^{-1}\right)(\mathrm{CQFSRS} / \mathrm{SC}$, 2004).

In the soil of both vineyards the highest organic $\mathrm{P}$ contents extracted by $0.5 \mathrm{~mol} \mathrm{~L}^{-1} \mathrm{NaHCO}_{3}$ were found in the surface layers, in vineyard 1 down to $10 \mathrm{~cm}$ and in vineyard 2 down to $5 \mathrm{~cm}$ (Table 2). But in the native grassland, the highest contents of organic $\mathrm{P}$ extracted by $0.5 \mathrm{~mol} \mathrm{~L}^{-1} \mathrm{NaHCO}_{3}$ were found in the $11-20 \mathrm{~cm}$ soil layer, in comparison with the top soil layer, which may be due to the absence of fertilization of this soil. This may have induced a dependence of $\mathrm{P}$ nutrition on the mineralization of this labile organic $\mathrm{P}$ by phosphatase extrusion, as shown by Rheinheimer et al. (2008).

In the vineyards, the highest contents of organic P extracted by $0.5 \mathrm{~mol} \mathrm{~L}^{-1} \mathrm{NaHCO}_{3}$ down to the 11-20 $\mathrm{cm}$ layer were observed in the vineyard 2 soil, as compared to the vineyard 1 soil and that of native grasslands, except for the soil in the 11-20 cm layer of native grasslands. The higher organic $\mathrm{P}$ content extracted by $0.5 \mathrm{~mol} \mathrm{~L}^{-1} \mathrm{NaHCO}_{3}$, especially in the 0-5 and 6-10 cm layer of the soils of vineyards 1 and 2 , may be attributed to the deposition and posterior decomposition of litter of the above-ground part of cover species that co-habit the vineyards, as well as pruned branches, dead grapevine leaves and even senescent roots, both from the cover crop and grapevines (Brunetto et al., 2011).

The fractions of inorganic $P$ extracted by $0.1 \mathrm{~mol}$ $\mathrm{L}^{-1} \mathrm{NaOH}$ from the soil of native grasslands were equal down to a depth of $20 \mathrm{~cm}$, but in the vineyard soils, the contents were highest in the $0-5 \mathrm{~cm}$ layer (Table 3). The inorganic $\mathrm{P}$ contents extracted by 0.1 and $0.5 \mathrm{~mol} \mathrm{~L}^{-1} \mathrm{NaOH}$ in all layers evaluated were highest in both vineyard soils, which can be attributed in part to the history of fertilization to the vineyard soils. On the other hand, the organic $\mathrm{P}$ contents extracted by $0.1 \mathrm{~mol} \mathrm{~L}^{-1} \mathrm{NaOH}$ from the native grassland were higher down to a depth of $10 \mathrm{~cm}$, but in the soil of vineyard 1 , highest contents were found down to the 0-5 cm layer, and in the soil of vineyard 2 , they were equal down to the depth of $20 \mathrm{~cm}$ 
Table 3. Inorganic and organic $\mathrm{P}$ extracted with 0.1 and $0.5 \mathrm{~mol} \mathrm{~L}^{-1} \mathrm{NaOH}$ from a sandy Typic Hapludalf soil of a grassland site, vineyard 1 (age 14 years) and vineyard 2 (age 30 years), in three layers

\begin{tabular}{|c|c|c|c|c|c|}
\hline$P$ fraction & Soil layer & Grassland site & Vineyard 1 & Vineyard 2 & $\mathbf{C V}$ \\
\hline & $\mathrm{cm}$ & 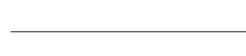 & $-\mathrm{mg} \mathrm{kg}^{-1}$ & & $\%$ \\
\hline \multirow{4}{*}{$\mathrm{NaOH} 0.1 \mathrm{~mol} \mathrm{~L}^{-1}$ inorganic $\mathrm{P}$} & $0-5$ & $11.9 \mathrm{aB}$ & $34.6 \mathrm{aA}$ & $32.3 \mathrm{aA}$ & 6.72 \\
\hline & $6-10$ & $7.6 \mathrm{aB}$ & $29.2 \mathrm{bA}$ & $25.3 \mathrm{bA}$ & 4.10 \\
\hline & $11-20$ & $11.4 \mathrm{aB}$ & $20.5 \mathrm{cA}$ & $23.0 \mathrm{cA}$ & 5.88 \\
\hline & $\mathrm{CV}(\%)$ & 16.85 & 4.03 & 2.77 & \\
\hline \multirow{4}{*}{$\mathrm{NaOH} 0.1 \mathrm{~mol} \mathrm{~L}^{-1}$ organic $\mathrm{P}$} & $0-5$ & $8.9 \mathrm{abB}$ & $29.4 \mathrm{aA}$ & $25.8 \mathrm{aA}$ & 15.90 \\
\hline & $6-10$ & $10.0 \mathrm{aB}$ & $18.9 \mathrm{bA}$ & $25.9 \mathrm{aA}$ & 2.19 \\
\hline & $11-20$ & $6.2 \mathrm{bB}$ & $19.9 \mathrm{bA}$ & $20.8 \mathrm{aA}$ & 6.20 \\
\hline & CV $(\%)$ & 12.15 & 5.09 & 13.57 & \\
\hline \multirow{4}{*}{$\mathrm{NaOH} 0.5 \mathrm{~mol} \mathrm{~L}^{-1}$ inorganic $\mathrm{P}$} & $0-5$ & $7.2 \mathrm{aB}$ & $18.7 \mathrm{aA}$ & $14.5 \mathrm{aA}$ & 4.72 \\
\hline & $6-10$ & $4.6 \mathrm{bB}$ & $14.7 \mathrm{bA}$ & $12.5 \mathrm{bA}$ & 9.20 \\
\hline & $11-20$ & $6.7 \mathrm{aB}$ & $11.8 \mathrm{cA}$ & $12.0 \mathrm{bA}$ & 4.38 \\
\hline & $\mathrm{CV}(\%)$ & 9.23 & 2.70 & 4.30 & \\
\hline \multirow{4}{*}{$\mathrm{NaOH} 0.5 \mathrm{~mol} \mathrm{~L}^{-1}$ organic $\mathrm{P}$} & $0-5$ & $2.1 \mathrm{aC}$ & $4.5 \mathrm{aB}$ & $9.4 \mathrm{aA}$ & 5.29 \\
\hline & $6-10$ & $3.7 \mathrm{aA}$ & $2.6 \mathrm{bA}$ & $2.9 \mathrm{bA}$ & 14.07 \\
\hline & $11-20$ & $0.2 \mathrm{bB}$ & $0.2 \mathrm{cB}$ & $1.3 \mathrm{cA}$ & 13.96 \\
\hline & $\mathrm{CV}(\%)$ & 19.18 & 13.19 & 4.26 & 19.18 \\
\hline
\end{tabular}

Mean values followed by the same letter in the column and mean values followed by the same capital letter in the row, in the comparison of soil layers, are not significantly different (Tukey test, $\mathrm{p}<0.05$ ).

(Table 3). However, the highest organic $\mathrm{P}$ contents extracted by $0.1 \mathrm{~mol} \mathrm{~L}^{-1} \mathrm{NaOH}$ from all layers were found in the vineyard soils. This result confirms the data obtained by Araújo et al. (1993) who, in a Typic Hapludalf soil under sugar cane and with a history of soluble phosphate fertilization of 25 years, observed an accumulation of $\mathrm{P}$ extracted by $0.1 \mathrm{~mol} \mathrm{~L}^{-1} \mathrm{NaOH}$ in the soil profile compared to a native forest reference soil. The authors attribute this to the accumulation of inorganic $\mathrm{P}$ beyond the plant uptake capacity, causing an accumulation of organic $\mathrm{P}$ in the soil.

The inorganic $\mathrm{P}$ content and organic $\mathrm{P}$ extracted by $0.5 \mathrm{~mol} \mathrm{~L}^{-1} \mathrm{NaOH}$ were highest in the $0-5$ and $6-10$ $\mathrm{cm}$ layers, respectively, in native grassland soil. On the other hand, in the vineyard soils, the inorganic $\mathrm{P}$ contents and organic $\mathrm{P}$ extracted by $0.5 \mathrm{~mol} \mathrm{~L}^{-1} \mathrm{NaOH}$ were highest in the $0-5 \mathrm{~cm}$ layer. The inorganic $\mathrm{P}$ contents extracted by $0.5 \mathrm{~mol} \mathrm{~L}^{-1} \mathrm{NaOH}$ were similar in the vineyard soils in all layers, but were higher than under native grassland, as similarly found by fractionation with the other extractants. The organic $\mathrm{P}$ contents extracted by $0.5 \mathrm{~mol} \mathrm{~L}^{-1} \mathrm{NaOH}$ were higher in the $0-5$ and $11-20 \mathrm{~cm}$ layers in vineyard 2 as compared to the soil of vineyard 1 and native grasslands. These higher organic $\mathrm{P}$ contents extracted by $0.1 \mathrm{~mol} \mathrm{~L}^{-1} \mathrm{NaOH}$ and organic $\mathrm{P}$ extracted by 0.5 mol L ${ }^{-1} \mathrm{NaOH}$ in both vineyard soils may be associated with successive deposition of crop litter on the soil surface, both in vineyard 1 and vineyard 2 , especially in the latter, cultivated for 30 years, compared to the 14 years of vineyard 1 (Boschetti et al., 2009).
The higher $\mathrm{P}$ content extracted by $0.1 \mathrm{~mol} \mathrm{~L}^{-1}$ $\mathrm{NaOH}$ and $0.5 \mathrm{~mol} \mathrm{~L}^{-1} \mathrm{NaOH}$ from the surface layers of the native grassland soil could indicate that, in contrast to the fate of organic $\mathrm{P}$ extracted by $\mathrm{NaHCO}_{3}$ fraction, the organic forms extracted by $\mathrm{NaOH}$ from the surface layers are not used by the plants through mineralization. Several studies cited in the review of Cross \& Schlesinger (1995) showed that while the fraction extracted by $\mathrm{NaHCO}_{3}$ extracts fractions that are labile for plants, the fraction extracted by $\mathrm{NaOH}$ acts as a $\mathrm{P}$ sink, especially when $\mathrm{P}$ fertilization exceeds plant requirements.

The highest inorganic $\mathrm{P}$ contents extracted by $1 \mathrm{~mol} \mathrm{~L}^{-1} \mathrm{HCL}$ were found in the surface soil layer $(0-5 \mathrm{~cm})$ of all three evaluated areas (Table 4). Comparing the treatments, the highest content was found in vineyard 2 in all layers, which has a greater age and longer sequence of phosphate fertilization, followed by the soil of vineyard 1 . It is important to note that the inorganic $P$ extracted by $1 \mathrm{~mol} \mathrm{~L}^{-1} \mathrm{HCL}$ related to calcium is usually derived from primary minerals; however, in moderately weathered soils, such as those found in the area of the present study, the occurrence of apatite is rare, not supporting this hypothesis. A plausible hypothesis was established by Rheinheimer \& Anghinoni (2001), who comment that in soils in the no-tillage system in southern Brazil, an increase in $\mathrm{P}$ calcium fractions may occur in the soil subjected to continuous application of phosphate fertilizer on the soil surface layer plus higher contents of exchangeable $\mathrm{Ca}$ in the same layer. Thus, it is likely 
that a similar phenomenon occurred in these two vineyards, especially in vineyard 2 , because generally winegrowers do not define the need and the amount of $\mathrm{P}$ in vineyard soils based on technical criteria established for the crop, such as soil and foliar analysis and grape yield expectations and therefore nutrients are applied beyond crop requirements.

The residual $\mathrm{P}$ content extracted by $\mathrm{H}_{2} \mathrm{SO}_{4}+\mathrm{H}_{2} \mathrm{O}_{2}$ $+\mathrm{MgCl}_{2}$, which is a recalcitrant fraction of $\mathrm{P}$ resistant to selective chemical extractants in the soil and which can only contribute to plant nutrition under extreme P-deficiency (Gatiboni et al., 2007), was equal among the soil layers of native grassland (Table 4). In the vineyard soils, the contents differed significantly among depths (highest content in the $0-5 \mathrm{~cm}$ layer). However, it was also observed that the HCl-extracted $P$ fraction in the $6-10 \mathrm{~cm}$ layer of in vineyard 1 corresponded to $33 \%$ of the content in the $0-5 \mathrm{~cm}$ layer, while in vineyard 2 this content was $68 \%$. This may indicate that the soil in vineyard 2 had already reached its maximum retention capacity of this $\mathrm{P}$ fraction.

The highest residual $P$ contents in all soil layers were found in the soil of vineyard 1 . This may be due to higher $\mathrm{Fe}$ oxide contents extracted by dithionitecitrate-bicarbonate and ammonium oxalate (Table 1). These data agree with those of Santos et al. (2008) who, in a sandy Typic Hapludalf soil with clayey texture and phosphate fertilization $\left(180 \mathrm{~kg} \mathrm{P}_{2} \mathrm{O}_{5}\right.$ ha $\left.^{-1}\right)$ in three growing seasons of corn, found a predominance of residual $\mathrm{P}$ in the $0-20 \mathrm{~cm}$ layer.

Figure 1 shows the accumulated $P$ fractions found in the three layers of all three studied areas. Most $P$ was accumulated in the residual $P$ fraction, followed by the inorganic $\mathrm{P}$ fraction extracted by $0.1 \mathrm{~mol} \mathrm{~L}^{-1}$ $\mathrm{NaOH}$ and organic $\mathrm{P}$ extracted by $0.1 \mathrm{~mol} \mathrm{~L}^{-1} \mathrm{NaOH}$ from all three studied soils. Similar results were found by Gonçalves \& Meurer (2009), who reported that in many soils of southern Brazil, including some with a history of application of phosphate fertilizers, most soil $\mathrm{P}$ was contained in the residual fraction. The highest accumulation of labile inorganic $\mathrm{P}$ of all three studied areas was found in vineyard 2 , which reinforces the tendency to $\mathrm{P}$ transfer in this soil.

Similar results were found by Rheinheimer et al. (2003), who reported $P$ accumulation in labile fractions in soil with phosphate fertilizer. Moreover, the greatest $P$ accumulation was found in vineyard 2 in the organic $\mathrm{P}$ fractions extracted by $0.5 \mathrm{~mol} \mathrm{~L}^{-1} \mathrm{NaOH}$ and the inorganic $\mathrm{P}$ extracted by $1 \mathrm{~mol} \mathrm{~L}^{-1} \mathrm{HCL}$.

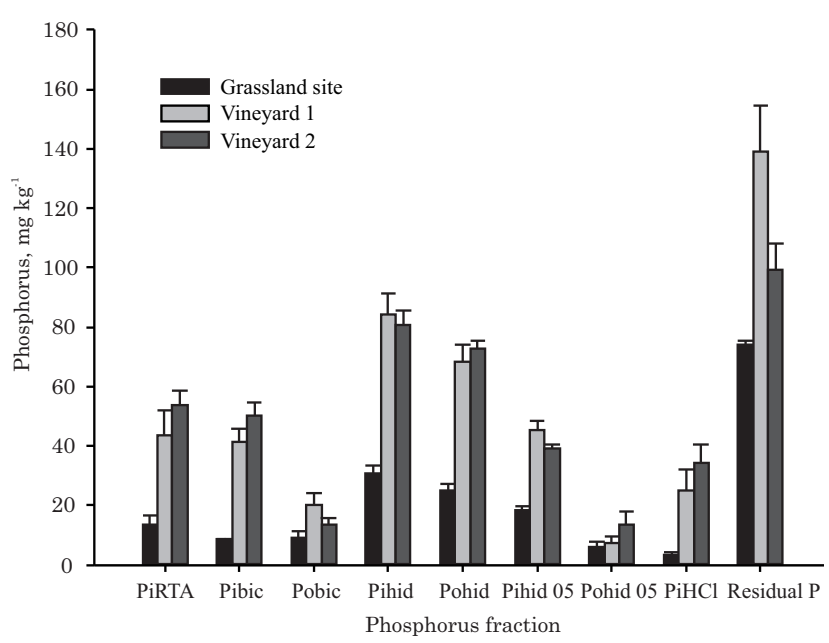

Figure 1. Sum of the $P$ content of different fractions in the three layers, in a sandy Typic Hapludalf soil under native grassland and of vineyard 1 (age 14 years) and vineyard 2 (age 30 years). $\mathbf{P i}_{\text {RTA }}$, inorganic $\mathbf{P}$ extracted by anion-exchange resin; $\mathbf{P i}_{\text {bic }}$ and $\mathbf{P o}_{\text {bic }}$ : inorganic and organic $\mathbf{P}$ extracted by $0.5 \mathrm{~mol} \mathrm{~L}^{-1} \mathrm{NaHCO}_{3} ; \mathrm{Pi}_{\text {hid }}$ and $\mathrm{Po}_{\text {hid }}$ : inorganic and organic $\mathrm{P}$ extracted by $\mathrm{NaOH} 0.1$ mol L-1 $\mathrm{Pi}_{\text {hid05 }}$ and $\mathrm{Po}_{\text {hid05 }}$ inorganic and organic $\mathrm{P}$ extracted by $\mathrm{NaOH} 0.5 \mathrm{~mol} \mathrm{~L}^{-1} ; \mathrm{Pi}_{\mathrm{HCl}}$, inorganic $P$ extracted by 1 mol L-1 HCL; $P_{\text {residual, }} \mathbf{P}$ extracted by $\mathrm{H}_{2} \mathrm{SO}_{4}+\mathrm{H}_{2} \mathrm{O}_{2}+\mathrm{MgCl}_{2}$.

Table 4. Inorganic P extracted by $1 \mathrm{~mol} \mathrm{L-1}$ HCL and residual P fractions in a sandy Typic Hapludalf soil of a grassland site, vineyard 1 (age 14 years) and vineyard 2 (age 30 years), in three layers

\begin{tabular}{|c|c|c|c|c|c|}
\hline$P$ fraction & Soil layer & Grassland site & Vineyard 1 & Vineyard 2 & CV \\
\hline & $\mathrm{cm}$ & 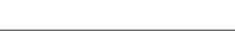 & $-\mathrm{mg} \mathrm{kg}^{-1}$ & & $\%$ \\
\hline \multirow{4}{*}{$\mathrm{HCl}$ inorganic $\mathrm{P}$} & $0-5$ & $2.0 \mathrm{aC}$ & $16.4 \mathrm{aB}$ & $17.3 \mathrm{aA}$ & 2.22 \\
\hline & $6-10$ & $0.7 \mathrm{bC}$ & $5.4 \mathrm{bB}$ & $11.8 \mathrm{bA}$ & 4.02 \\
\hline & $11-20$ & $0.6 \mathrm{bC}$ & $3.3 \mathrm{cB}$ & $5.2 \mathrm{cA}$ & 5.84 \\
\hline & CV (\%) & 16.08 & 3.86 & 1.21 & \\
\hline \multirow{4}{*}{ Residual P } & $0-5$ & $25.7 \mathrm{aC}$ & $64.1 \mathrm{aA}$ & $42.9 \mathrm{aB}$ & 4.25 \\
\hline & $6-10$ & $23.7 \mathrm{aC}$ & $39.7 \mathrm{bA}$ & $30.0 \mathrm{bB}$ & 3.11 \\
\hline & $11-20$ & $24.8 \mathrm{aB}$ & $35.3 \mathrm{bA}$ & $26.3 \mathrm{bB}$ & 4.26 \\
\hline & $\mathrm{CV}(\%)$ & 4.01 & 4.79 & 4.02 & \\
\hline
\end{tabular}

Mean values followed by the same letter in the column and mean values followed by the same capital letter in the row, comparing soil layers, are not significantly different (Tukey test, $\mathrm{p}<0.05$ ). 
Although the greatest content in absolute terms was detected in the residual $\mathrm{P}$ fraction, the greatest $\mathrm{P}$ increases due to phosphate fertilization in relation to native grassland soil were found in the inorganic $\mathrm{P}$ fraction extracted by $1 \mathrm{~mol} \mathrm{~L}^{-1} \mathrm{HCL}$, an increase of $660.6 \%$ and $939.4 \%$ for vineyard 1 and 2 , respectively, followed by increases in the inorganic $\mathrm{P}$ fractions extracted by anion-exchange resin and $0.5 \mathrm{~mol} \mathrm{~L}^{-1}$ $\mathrm{NaHCO}_{3}$, respectively.

It can be inferred that in soils with a longer history of $\mathrm{P}$ application, there was an increase in the element, especially in the non-labile fraction extracted by $1 \mathrm{~mol}$ $\mathrm{L}^{-1} \mathrm{HCL}$ and in the labile fraction extracted by anionexchange resin and $0.5 \mathrm{~mol} \mathrm{~L}^{-1} \mathrm{NaHCO}_{3}$. These results are in agreement with those obtained by Pavinato et al. (2009), who reported that in a clay-loam textured Typic Hapludox, with a history of phosphate fertilization and annual crops, $\mathrm{P}$ was accumulated in moderately labile fractions extracted by 0.1 and 0.5 $\mathrm{mol} \mathrm{L}^{-1} \mathrm{NaOH}$ throughout the soil profile, which can be used by crops in cases of lack of available $\mathrm{P}$ (Gatiboni et al., 2007; Santos et al., 2008).

The geochemical $\mathrm{P}$ content obtained by the sum of fractions extracted by anion-exchange resin + $0.5 \mathrm{~mol} \mathrm{~L}^{-1} \mathrm{NaHCO}_{3}+0.1 \mathrm{~mol} \mathrm{~L}^{-1} \mathrm{NaOH}+0.5 \mathrm{~mol} \mathrm{~L}^{-1}$ $\mathrm{NaOH}+1 \mathrm{~mol} \mathrm{~L}^{-1} \mathrm{HCL}+$ residual $\mathrm{P}$ were highest in the $0-5 \mathrm{~cm}$ layer, in all three evaluated soils (Table $5)$. However, highest contents were found in the $0-5$ and 6-10 $\mathrm{cm}$ layers in vineyard 1 soil, and in the 11-20 $\mathrm{cm}$ layer in vineyard 2 . Furthermore, the geochemical $\mathrm{P}$ contents in all soil layers of both vineyards were higher than in the native grassland soil. Biological $\mathrm{P}$ contents from the sum of the organic fractions $(0.5$ $\mathrm{mol} \mathrm{L}^{-1} \mathrm{NaHCO}_{3}+0.1 \mathrm{~mol} \mathrm{~L}^{-1} \mathrm{NaOH}+0.5 \mathrm{~mol} \mathrm{~L}^{-1}$ $\mathrm{NaOH}$ ) in the native grassland soil were higher in the $6-10 \mathrm{~cm}$ layer. In the vineyard soils, the content was highest in the 0-5 cm layer, where the highest value of total organic carbon was found (Table 1). However, in all layers, the values of biological $\mathrm{P}$ were highest in the vineyard soils.

Studies in Brazil have shown increasing organic $\mathrm{P}$ in the soil profile, especially in soils with phosphate fertilization under no tillage (Galvani et al., 2008; Oliboni $\&$ Rosolem, 2010). This can be partly explained by the absence of soil tilling over the years and crop litter deposition on the soil surface (Tokura et al., 2002). But, in addition, it is important to mention that in soils with high $\mathrm{P}$ accumulation in inorganic forms, as for example in vineyard soil, plants generally use less of the organic $P$ fractions (Gatiboni et al., 2008). The highest total $P$ contents, which represent the sum of all fractions of the element, were observed in the 0-5 cm layer in both vineyard and native grassland soils (Table 5). But in all layers, higher contents were found in the vineyard soils than under native grassland, according to results obtained from geochemical $\mathrm{P}$ and biological $\mathrm{P}$.

\section{CONCLUSIONS}

1. By excessive applications of phosphate fertilizers before planting and as maintenance fertilization in vineyards, particularly in the older vineyard, the inorganic $\mathrm{P}$ content increased down to a depth of 20 $\mathrm{cm}$, especially in the labile fractions extracted by anionexchange resin and $\mathrm{NaHCO}_{3}$, in the moderately labile fraction extracted by 0.1 and $0.5 \mathrm{~mol} \mathrm{~L}^{-1} \mathrm{NaOH}$, and in the non-labile fraction extracted by $1 \mathrm{~mol} \mathrm{~L}^{-1} \mathrm{HCL}$, indicating possible water eutrophication.

Table 5. Geochemical and biological P pools, and sum of all P fractions in a sandy Typic Hapludalf soil of a grassland site, vineyard 1 (age 14 years) and vineyard 2 (age 30 years), in three layers

\begin{tabular}{|c|c|c|c|c|c|}
\hline$P$ fraction & Soil layer & Grassland site & Vineyard 1 & Vineyard 2 & CV \\
\hline \multirow{5}{*}{ Geochemical P } & $\mathrm{cm}$ & 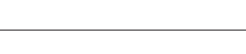 & $-\mathrm{mg} \mathrm{kg}^{-1}$ & & $\%$ \\
\hline & $0-5$ & $57.6 \mathrm{aC}$ & $174.1 \mathrm{aA}$ & $151.8 \mathrm{aB}$ & 2.40 \\
\hline & $6-10$ & $42.9 \mathrm{bC}$ & $119.2 \mathrm{bA}$ & $112.0 \mathrm{bB}$ & 1.01 \\
\hline & $11-20$ & $48.2 \mathrm{bC}$ & $85.5 \mathrm{cB}$ & $93.1 \mathrm{cA}$ & 2.55 \\
\hline & CV $(\%)$ & 3.75 & 2.19 & 1.06 & \\
\hline \multirow{3}{*}{ Biological P } & $0-5$ & $12.6 \mathrm{abB}$ & $43.6 \mathrm{aA}$ & $44.0 \mathrm{aA}$ & 9.38 \\
\hline & $6-10$ & $16.1 \mathrm{aB}$ & $30.1 \mathrm{bA}$ & $33.9 \mathrm{bA}$ & 6.50 \\
\hline & $11-20$ & $11.6 \mathrm{bC}$ & $22.1 \mathrm{cB}$ & $27.6 \mathrm{bA}$ & 5.92 \\
\hline \multirow{5}{*}{ Sum of all fractions } & $\mathrm{CV}(\%)$ & 10.88 & 5.44 & 7.48 & \\
\hline & $0-5$ & $70.1 \mathrm{aC}$ & $217.6 \mathrm{aA}$ & $195.7 \mathrm{aB}$ & 2.50 \\
\hline & $6-10$ & $59.0 \mathrm{bB}$ & $149.3 \mathrm{bA}$ & $145.9 \mathrm{bA}$ & 1.96 \\
\hline & $11-20$ & $59.8 \mathrm{bC}$ & $107.7 \mathrm{cB}$ & $120.7 \mathrm{cA}$ & 2.70 \\
\hline & $\mathrm{CV}(\%)$ & 2.48 & 1.13 & 2.48 & \\
\hline
\end{tabular}

Mean values followed by the same letter in the column and mean values followed by the same capital letter in the row, comparing soil layers, are not significantly different (Tukey test, $\mathrm{p}<0.05$ ). 
2. Phosphate fertilization and a longer cultivation period of grapevine increased the $\mathrm{P}$ content in the labile organic fraction extracted by $\mathrm{NaHCO}_{3}$ from the $0-5$ $\mathrm{cm}$ soil layer, and especially in the moderately labile fraction extracted by $0.1 \mathrm{~mol} \mathrm{~L}^{-1} \mathrm{NaOH}$, down to a depth of $20 \mathrm{~cm}$.

\section{ACKNOWLEDGEMENTS}

The authors are indebted to the National Council of Technological and Scientific Development (CNPq) for financial support (Project CNPq no. 471671/20100 ). The first and sixth author thank the CAPES for the postgraduate scholarships. The third and tenth author thank the CNPq for research grants.

\section{LITERATURE CITED}

ARAÚJO, M.S.B.; SALCEDO, I.H. \& SAMPAIO, E.V.S.V. Efeitos de fertilizações fosfatadas anuais em solos cultivado com cana-de-açúcar I. Intensidade e formas de acumulação. R. Bras. Ci. Solo, 17:389-396, 1993.

BosChetTI, N.G.; QUINTERO, C.E. \& GIUFFRE, L. Phosphorus fractions of soils under Lotus corniculatus as affected by different phosphorus fertilizers. Biol. Fert. Soil, 45:379-384, 2009.

BRUNETTO, G.; VENTURA, M.; SCANDELLARI, F.; CERETTA, C.A.; KAMINSKI, J.; MELO, G.W.B. \& TAGLIAVINI, M. Nutrient release during the decomposition of mowed perennial ryegrass and white clover and its contribution to nitrogen nutrition of grapevine. Nutr. Cycl. Agroecosyst., 90:299-308, 2011.

COMISSÃO DE QUÍMICA E FERTILIDADE DO SOLO CQFSRS/SC. Manual de adubação e de calagem para os Estados do Rio Grande do Sul e Santa Catarina. Porto Alegre, Sociedade Brasileira de Ciência do Solo/Núcleo Regional Sul, 2004. 400p.

CONDRON, L.M. \& GOH, K.M. Effects of long-term phosphatic fertilizer applications on amounts and forms of phosphorus in soils under irrigated pasture in New Zealand. J. Soil Sci., 40:383-395, 1989.

CROSS, A.F. \& SCHLESINGER, W.H. A literature review and evaluation of the Hedley fractionation: Applications to the biogeochemical cycle of soil phosphorus in natural ecosystems. Geoderma, 64:197-214, 1995.

DICK, W.A. \& TABATABAI, M.A. Determination of orthophosphate in aqueous solutions containing labile organic and inorganic phosphorus compounds. J. Environ. Qual., 6:82-85, 1977.

EMPRESA BRASILEIRA DE PESQUISA AGROPECUÁRIA EMBRAPA. Centro Nacional de Pesquisa do Solo. Manual de métodos de análise de solos. 2.ed. Rio de Janeiro, 1997. 212p.

GALVANI, R.; HOTTA, L.F.K. \& ROSOLEM, C.A. Phosphorus sources and fractions in an oxisol under no-tilled soybean. Sci. Agric., 65:415-421, 2008.
GATIBONI, L.C.; BRUNETTO, G.; KAMINSKI, J.; RHEINHEIMER, D.S.; CERETTA, C.A. \& BASSO, C.J. Formas de fósforo no solo após sucessivas adições de dejeto líquido de suínos em pastagem natural. R. Bras. Ci. Solo., 32:1753-1761, 2008.

GATIBONI, L.C.; KAMINSKI, J.; RHEINHEIMER, D.S. \& FLORES, J.P.C. Biodisponibilidade de formas de fósforo acumuladas em solo sob sistema plantio direto. R. Bras. Ci. Solo, 31:691-669, 2007.

GONÇALVES, G.K. \& MEURER, E.J. Frações de fósforo no solo e sua relação com a absorção pelas plantas de arroz irrigado por alagamento em solos do Rio Grande do Sul. R. Bras. Ci. Solo, 33:357-362, 2009.

HEDLEY, M.J.; STEWART, J.W.B. \& CHAUHAN, B.S. Changes in inorganic and organic soil phosphorus fractions induced by cultivation practices and by laboratory incubations. Soil Sci. Soc. Am. J., 46:970-976, 1982.

HERLIHY, M. \& McGRATH, D. Phosphorus fractions and adsorption characteristics in grassland soils of soil phosphorus status. Nutr. Cycl. Agroecost., 77:15-27, 2007.

LINQUIST, B.A.; RUARK, M.D. \& HILL, J.E. Soil order and management practices control soil phosphorus fractions in managed wetland ecosystems. Nutr. Cycl. Agroecosyst., 90:51-62, 2011.

MEHRA, O.P. \& JACKSON, M.L. Iron oxide removal from soils by a dithionite-citrate system buffered with sodium bicarbonate. Clay. Clay. Miner., 7:317-327, 1960.

MURPHY, J. \& RILEY, J.P. A modified single solution method for the determination of phosphate in natural waters. Anal. Chim. Acta., 27:31-36, 1962.

NEGASSA, W. \& LEINWEBER, P. How does the Hedley sequential phosphorus fractionation reflect impacts of land use and management on soil phosphorus: A review. J. Plant Nutr. Soil Sci., 172:305-325, 2009.

OLIBONI, D. \& ROSOLEM, C.A. Phosphate fertilization and phosphorus forms in an Oxisol under no-till. Sci. Agric., 67:465-471, 2009.

PAVINATO, P.S.; MERLIN, A. \& ROSOLEM, C.A. Phosphorus fractions in Brazilian Cerrado soils as affected by tillage. Soil Tillage Res., 105:149-155, 2009.

RHEINHEIMER, D.S.; MARTINAZZO, R.; GATIBONI, L.C.; KAMINSKI, J. \& SILVA, L.S. Amplitude no fósforo microbiano em um Argissolo em pastagem nativa submetida à roçada e à introdução de espécies forrageiras com fertilização fosfatada em diferentes épocas. Acta Sci. Agron., 30:561-567, 2008.

RHEINHEIMER, D.S.; ANGHINONI, I. \& CONTE, E. Sorção de fósforo em função do teor inicial e de sistemas de manejo de solos. R. Bras. Ci. Solo., 27:41-49, 2003.

RHEINHEIMER, D.S. \& ANGHINONI, I. Distribuição do fósforo inorgânico em sistemas de manejo de solo. Pesq. Agropec. Bras., 36:151-160, 2001.

SANTOS, J.Z.L.; FURTINI, A.E.N.; RESENDE, Á.V.; CURI, N.; CARNEIRO, L.F. \& COSTA, S.E.V.G.A. Frações de fósforo em solo adubado com fosfatos em diferentes modos de aplicação e cultivado com milho. R. Bras. Ci. Solo., 32:705-714, 2008. 
SAS Institute Inc®. SAS versão 9.1.3. Cary, 2003.

SOIL SURVEY STAFF. Soil Taxonomy. 2.ed. Washington, United States Department of Agriculture, 1999.

TEDESCO, M.J.; GIANELLO, C.; BISSANI, C.; BOHNEN, H. \& VOLKWEISS, S.J. Análise de solo, plantas e outros materiais. 2.ed. Porto Alegre, Universidade Federal do Rio Grande do Sul, 1995. 174p.
TOKURA, A.M.; FURTINI NETO, A.E.; CARNEIRO, F.C.; CURI, N.; SANTOS, J.Z.L. \& ALOVISI, A.A. Dinâmica das formas de fósforo em solos de textura e mineralogia contrastantes cultivados com arroz. Acta Sci. Agron., 33:171-179, 2011.

TOKURA, A.M.; FURTINI NETO, A.E.; CURI, N.; FAQUIN, V.; KURIHARA, C.H. \& ALOVISI, A.A. Formas de fósforo em solo sob plantio direto em razão da profundidade e tempo de cultivo. Pesq. Agropec. Bras., 37:1467-1476, 2002. 